DOI: $10.2478 /$ ausp-2014-0008

\title{
Representations of Female Alterity in Contemporary Hungarian and Romanian Cinema $^{1}$
}

\author{
Judit PIELDNER \\ Sapientia University, Miercurea Ciuc \\ Department of Humanities \\ juditpieldner@yahoo.com
}

\begin{abstract}
The present study carries out a comparative/contrastive analysis of two ways of contemporary Hungarian and Romanian film discourse, namely magic realism and micro-realism, and will focus on the representation of the woman in the contemporary films entitled Witch Circle (Dezső Zsigmond, 2009), exploring a subversive female mythologem of a confined traditional community, that of the Csángó people, Bibliothèque Pascal (Szabolcs Hajdú, 2010), which creates a private mythology, materialised in form of surrealist images, of the female self interpreting herself out of her conditions, and Beyond the Hills (Cristian Mungiu, 2012), drawing its topic from a real event —reality generating fiction-that inspired Tatiana Niculescu Bran's Deadly Confession (Spovedanie la Tanacu), Judges' Book (Cartea Judecătorilor), as well as Zsolt Láng's The Monastery of Protection (Az oltalom kolostora). Beyond dealing with related female patterns, the films under discussion are engaged in mediating collective and private mental representations, as well as in creating film narratives with the convergent feature of juxtaposing the real and the mythical. The films approach the topic from distinct possibilities of cinematic representation and offer, in my view, a complementary and intercultural image of the woman trapped between the East and the West, between social and religious institutions and victimised by the stereotypical view of society.
\end{abstract}

Keywords: magic realism, micro-realism, real vs. mythical, stereotypes, female identity and alterity

\section{Introduction}

Ever since the change of the political regime in Hungary and Romania, several literary and cinematic attempts have emerged to depict the socio-cultural realities of Eastern Europe, to cope with the past traumas experienced by both

1 The study was created within the framework of the three-year group research programme Imagology Researches, supported by the Institute of Research Programmes of Sapientia University. 
nations, to revive collective and cultural memory, to grab the Eastern European specificity that makes the region the "other" of (Western) Europe. In the past two decades that have passed since the fall of the iron curtain it has turned out that what used to be conceived-or rather ideologically imposed-as a homogeneous space in political, cultural and ethnic terms, got transformed into a polymorph, heterogeneous, multidimensional one in several respects, a multilayered, palimpsest-zone which its inhabitants both identify with and get estranged from, a zone where global supermodernity is in perpetual conflict with local, cultural and religious traditions; the reader/spectator is confronted with the experience of incompatibilities in several artistic representations.

Several Hungarian and Romanian films set themselves the task of processing the-collective and individual—trauma experienced in the communist regime, ${ }^{2}$ revaluing the Romanian revolution, unveiling mechanisms of mediation, ${ }^{3}$ as well as analysing the relationship between private memory and cultural memory, the quest for the past as a self-quest. ${ }^{4}$

Besides the attention focused on the past, several cinematic representations of women have been created, focusing on issues such as women and trauma, women between the East and the West, women trapped by social institutions/taboos, the female body as a carrier of the spirit of the place and power relations, some of them reinforcing stereotypes, others nuancing the image and pointing at affinities that are at the core of the Eastern European (female) existence.

These films display various discursive trends, from the magic realist tendency in Hungarian films to the "New Wave" in Romanian cinema, as well as various stylistic and rhetorical specificities, from minimalism, microrealism, naturalism to excessive stylization, (self-)reflexivity, exploration of intermedial/interart relations.

The hypothesis of the present paper is that the issue of women in film is always also an issue pertaining to representation; female alterity implying thus, in most cases, some kind of medial alterity, specificity. This is why I examine the question of female alterity in connection with particular cinematic modes of representation, namely magic realism in contemporary Hungarian cinema and micro-realism in contemporary Romanian cinema.

2 e.g., The Way I Spent the End of the World (Cum mi-am petrecut sfârşitul lumii, Cătălin Mitulescu, 2006); 4 Months, 3 Weeks and 2 Days (4 luni, 3 săptămâni, şi 2 zile, Cristian Mungiu, 2007); Tales from the Golden Age (Amintiri din epoca de aur, Hanno Höfer, Răzvan Mărculescu, Cristian Mungiu, Constantin Popescu, Ioana Uricaru, 2009)

3 e.g., 12:8 East of Bucharest ( $A$ fost sau n-a fost?, Corneliu Porumboiu, 2006)

4 e.g., Moscow Square (Moszkva tér, Ferenc Török, 2001); White Palms (Fehér tenyér, Szabolcs Hajdú, 2006); Taxidermia (György Pálfi, 2006); Delta (Kornél Mundruczó, 2008). As for the topic of the past in contemporary Hungarian cinema, see Strausz (2011), and regarding the same topic in contemporary Romanian cinema, see Részeg (2011). 


\section{Tendencies of magic realism in contemporary Hungarian Cinema}

The first set of questions is related to what principles of storytelling the contemporary Hungarian films that can be labelled as "magic realist" assume and to what extent they contribute to the cinematic representation of the Central and Eastern European condition/paradigm, or rather, what kind of representational discourse they establish within the framework of the generic-discursive diversity of today's Hungarian film productions. Further on, my attention is turned towards the way the so-called "magic realist" narrative-representational discourse and the topic of female alterity, traumatised female identity are interlocked in particular films. Whereas Miklós Mészöly's prose turn after the publication of his novel entitled Film (1976) was still received in terms of the "South-American paradigm" in the literary criticism of the time, ever since Tamás Bényei's Apocriphal Documents was published in 1997, the term "magic realism" has been applied to contemporary Hungarian literary works as well, critics regarding the versions of this way of narrative discourse as a Central and Eastern European "specificity," influenced/ inspired by the South-American way of "seasoning." In today's Hungarian short story and novel writing practice there is a strong tendency of displaying a narratorial voice striving to enthrall the reader by turning natural elements into supernatural ones and vice versa, being characterised by a "double crowdedness" at the level of plot as well as rhetoric, by blending history and self-reflection, characterised by an excessive use of decorative and hyperbolical figures (cf. Bényei 1997). By definition, magic realism combines realism and the fantastic in such a way that magical elements grow organically out of the reality portrayed. It is not always unambiguous what the necessary and sufficient conditions for a literary work to be considered as "magic realist" are; however, works of mythical character, whether drawing from the historical-cultural tradition or from contemporary social realities, whether the fantastic element is imposed on or abstracted from the “real,” by authors such as László Darvasi, János Háy, Zsolt Láng, Éva Berniczky, András Cserna Szabó as well as Ádám Bodor and his followers, György Dragomán and Gábor Vida, enter the category under discussion. Tamás Bényei goes beyond reading the conceptually obscure term merely as an oxymoron as well as beyond automatically attaching the phenomenon to a particular geographical-cultural region and defines magic realism as an international phenomenon constituting an integrative part of postmodern discourse (Bényei 1997). The "magic" component of the phrase refers, on the one hand, to the visual aspects, to the rhetorical and narrative specificities of the literary discourse; on the other hand, it also implies an ontological layer of meaning, referring to a particular way of reading-by virtually transgressing the boundaries of-reality/existence. 
In parallel with the above-mentioned endeavours in contemporary Hungarian literature, in today's Hungarian cinema there is a tendency of representing the social, cultural, ethnic diversity and incompatibilities that characterise Central and Eastern European existence, a tendency of visually recreating a Balkan Macondo, the stereotypes of Balkan existence with all its ambivalences and absurdities, constituting the preconditions for the carnivalesque type of rendering (as it manifests in Emir Kusturica's oeuvre). Among the established discourses of contemporary Hungarian film, which I am going to briefly survey without the intention of being exhaustive, a number of films that attempt to transgress the boundaries of given realities and to make realms beyond discernible are regarded as experiments, inventions, even as "cuckoo's eggs," though a contemporary "Budapest Film School" speaking the language of magic realism is taking shape, is getting crystallised. Thus, among the generic diversity represented by popular genres such as the crime-thriller combination, ${ }^{5}$ the comedy, ${ }^{6}$ the films of comingof-age, of generation disposition; ${ }^{7}$ by art film genres such as film drama most powerfully represented by Béla Tarr's films, adaptation; ${ }^{8}$ by various experimental endeavours such as the non-narrative experiment, ${ }^{9}$ the remake, the opera film or the quasi-documentary, "magic realism" may appear as a genre-shaping dominant aiming at the (re-)territorialization of the imaginary ${ }^{10}$ or as a quality enriching the visual vocabulary of one of the above-mentioned genres. ${ }^{11}$

"Magic realism" may also be related to the inherently magic quality of filmic representation, acquiring media-conscious overtones, as in Ildikó Enyedi's films, especially in Simon, the Magician (Simon mágus, 1999). (The term "magic realism" was already used by Miklós Erdély, who suggested the term in order to define the way films by Bódy, Jeles, Tarr and Gothár transgressed the established modes of rendering.) It is to be mentioned that in contemporary Hungarian film criticism the inherent terminological obscurity of "magic realism" is preserved, as it is referred to as a generic, stylistic, even as an unspecified feature. All in all, we can detect an openness of contemporary film towards the mythical, the legendary, the miraculous, towards alternative entrances and exits of storytelling, as being qualities that lead to the shaping of a multilayered Central

5 e.g., The Detective (A nyomozó, Attila Gigor, 2008) or Hukkle (György Pálfi, 2002)

6 e.g., Only Sex and Nothing Else (Csak szex és más semmi, Krisztina Goda, 2005), Some Kind of America (Valami Amerika, Gábor Herendi, 2002), Glass Tyger (Üvegtigris, Iván Kapitány and Péter Rudolf, 2001)

7 e.g., Dad Would Have a Fit (Apám beájulna, Tamás Sas, 2003), Moscow Square (Moszkva tér, Ferenc Török, 2001)

8 e.g., Damnation (Kárhozat, Béla Tarr, 1988); Satan's Tango (Sátántangó, Béla Tarr, 1994); Werckmeister Harmonies (Werckmeister harmóniák, Béla Tarr, 2000); Fateless (Sorstalanság, Lajos Koltai, 2005)

$9 \quad$ e.g., Milky Way (Tejút, Benedek Fliegauf, 2007)

10 e.g., Bibliothèque Pascal (Szabolcs Hajdú, 2010)

11 e.g., Vespa (Diána Groó, 2010) 
and Eastern European mythological space, to the reanimation of the realm of the visual and simultaneously bring round a new familiarity—or rather intriguing unfamiliarity—as concerns spectatorship.

\section{Micro-realism as trademark of contemporary Romanian cinema}

Contemporary Romanian cinema employs another way of approaching the Eastern European condition. Doru Pop speaks about the common grammar of Romanian "new-new-wave" cinema, in which a dominant trope is "the preference for verism, the closeness of cinema to realism" $(2010,32)$. As the author argues,

As was the case of the Italian neo-realism, this new realism of the Romanian young cinema comes against the fictional-propaganda style of the "old" Romanian cinema, founded in a certain symbolic stage, where signification is generated by hidden meaning and collateral or subtle references. This is a direct cinema, in the very sense of addressing direct and abrupt issues, some of them ignored for decades. (32)

The elaboration of the specific minimalist-realist mode of representation which is a dominant characteristic of contemporary Romanian filmmaking, is linked to Cristi Puiu's name, to his first film entitled Stuff and Dough (Marfa şi banii, 2001). The term micro-realism covers more or less what we mean by Czech realism, having its representatives both in literature (Bohumil Hrabal) and in cinema (Miloš Forman), and is used to refer to representations of marginal, provincial spaces, absurd-grotesque twists and turns, tragicomic patterns, petty figures, anti-heroes, "lives of no great importance."

Although not all directors admit their categorisation into any kind of film school (see Fulger 2006), there seems to be a consensus in the critical discourse to speak about contemporary Romanian movies in terms of "new wave" or "newnew wave," and to characterise their mode of representation in terms of realism, micro-realism, verism, documentary style, direct cinema.

\section{The image of the woman: beyond the gender code}

Ever since Simone de Beauvoir's The Second Sex (1949) the word "woman" covers less a biological than a socially-culturally shaped entity; woman defined as "the Other" has revolutionised twentieth-century concepts of gender identity 
and gender roles. And ever since the emergence of post-structuralist feminist discourses, gender is a construct dependent on discursive practices.

In this sense, then, "sex" not only functions as a norm, but is part of a regulatory practice that produces the bodies it governs, that is, whose regulatory force is made clear as a kind of productive power, the power to produce-demarcate, circulate, differentiate the bodies it controls. Thus, "sex" is a regulatory ideal whose materialization is compelled, and this materialization takes place (or fails to take place) through certain highly regulated practices. (Butler 1993, 1)

The relationship between gender representation and film discourse is a favoured topic of film theory; maybe the most often cited essay in this respect is Laura Mulvey's Visual Pleasure and Narrative Cinema, which states that the pleasure of the traditional narrative film is based on the scopophilic instinct, that is, "the pleasure in looking at another person as an erotic object," the cinematic representation of woman induces voyeuristic-fetishistic mechanisms, and, on a psychoanalitic background, identifies mainstream cinema as the perpetuator of a patriarchal order in which the image of woman is "(passive) raw material for the (active) gaze of man” (Mulvey 1975).

The voyeuristic-fetishistic mechanism of the classical Hollywood film narrative has been overwritten by several cinematic discourses, trends and tendencies, distancing the image of the woman from being the object of the male gaze, providing sharp criticism of visual exposedness and oppression, offering a sensitive, reflective view of the complexity of female identity and alterity, of the female image as a complex implying both ethic and aesthetic considerations.

The image of woman indispensably reveals the onlooker's gaze, the perspective from which it is as it is shown. Representing women is by itself reflexive, as Hajnal Király states, "as long as it implicitly alludes to the (voyeuristic, fetishistic) gaze, and as such, it is suitable for metaphorically representing all kinds of rendered visuality" (Király 2010, 31, translated by me, J. P.).

Lately special attention has been devoted to various representations of women, to various topics related to female identity in contemporary Hungarian and Romanian cinematic endeavours. In contemporary cinematic representations woman appears as a vulnerable surface bearing the imprints of power relations. The female body comes to the fore as the product of mentalities/ideologies, as a specific carrier of profound spirituality, and last but not least, as a powerful medium transporting social criticism and urging a critical view of the overused term "reality."

With no claim of being exhaustive, I will make reference to a few recent studies which deal with the topic of representation of women in contemporary cinema. Júlia Éva Havas points out that in auteur cinema (used synonymously with art 
film) the representation of woman in film goes beyond the gender code, as the exposedness of woman implies the existential exposedness of the human being: "the ultimate exposedness to the other is not the exposedness of Woman to Man; instead of the gender code we must search for ontological solutions" (2011, 30, translated by me, J. P.).

László Strausz (2011) discusses Ágnes Kocsis’s Adrienn Pál (Pál Adrienn, 2010) in the context of the topic of memory with young Hungarian directors; the film relates the overweight nurse's search for her past friend, Adrienn Pál, displaying the story of a self-quest rather than a mere nostalgia for a former friendship.

Recent researches on cinematic representations of the woman also include comparative analyses of Hungarian and Romanian films, such as Lilla László's (2012) comparative study of Ágnes Kocsis's Fresh Air (Friss levegó, 2006) and Cristian Mungiu's 4 Months, 3 Weeks and 2 Days (4 luni, 3 săptămâni şi 2 zile, 2007), which examines cinematic space representation in connection with women protagonists, with women's lives and their bodies.

In her study entitled Surrogate Nature, Culture, Women-Inner Colonies. Postcolonial Readings of Contemporary Hungarian Films, by making use of the terms and arguments of post-colonialism, Mónika Dánél points out the underlying colonial schemes, mostly present in the representation of women, of Hungarian films set in Transylvania/Romania. ${ }^{12}$

\section{Reality transfigured: Witch Circle vs. Bibliothèque Pascal}

In what follows, I am going to contrast two films that touch upon related questions, both being preoccupied with the female condition and the possibility of "escape" through the visual rendering of a compound of collective consciousness and a private female imaginary realm respectively. I wish to point out essential differences in the strategies these films follow in order to create a sort of "magic realism" on the screen.

Before doing so, the inherent magic quality of the motion picture needs to be mentioned at the outset, as a consequence of which "magic realism," reality transfigured in/through film rhetoric, is of ontological significance as concerns the film medium. Similarly, the spectatorship of the film implies the magic of perception, a displaced and reordered functioning of the senses, defying "real" spatio-temporal experiences. But the contrast I intend to make goes beyond this generalising meaning and outlines the distinct effects the selected procedures exercise upon the viewer.

12 Among others, Delta (Kornél Mundruczó, 2008); Katalin Varga (Varga Katalin balladája, Peter Strickland, 2009); Witch Circle (Boszorkánykör, Dezső Zsigmond, 2009); Bibliothèque Pascal (Szabolcs Hajdú, 2010). 
I start from thematic contrasts within larger-scale parallels: in accordance with Dezső Zsigmond's interest in documenting confined, isolated, rural communities in which beliefs and superstitions are preserved, Witch Circle is aimed at representing the anthropological world of the Csángó people, more specifically, the beliefs related to the wild girls, whereas Szabolcs Hajdú's Bibliothèque Pascal is grounded upon urban social reality, and follows the destiny of a female individual.

The "rural" and the "urban" paradigms attain special overtones: though the beliefs centred around the wild girls allow the functioning of these female creatures escaped from the ties of society as a community, Mona Saparu's story (Bibliothèque Pascal) evolves into a prostitute story taking place in a brothel that strictly isolates women, hindering cooperation. Generically, Witch Circle implies a level-crossing detective thread (the investigation intersecting the irrational), while Bibliothèque Pascal relates a picaresque story, a story of maturisation nested into a frame.

As for the targeted spectator group of the former film is concerned, we get across anomalies: the "documentation" of myth, the "adaptation" of collective mental representations seem to be aimed at popularising the folklore element, and for this, authenticity has to be attained. However, casting authentic characters deriving from the respective area and having them say the text of the script reaches the very opposite effect of inauthenticity, artificiality. A number of authentic characters render verbally their experiences related to the supernatural creatures, trying to translate the events beyond perception into being palpable (they are either witnesses or partakers of the events). Still, they cannot capture the wild girls in their narrative traps as these creatures escape verbalisation, just as any other attempt of suppression.

The wild girls embody the male fear of the unharnessable, unsatisfiable woman, the projection of a collective female dream and male nightmare. The characters (acted by actors bringing along their heterogeneous origins, intended to form a homogeneous group) can be divided into the initiated (the wild girls themselves), those who believe in them, therefore respect them (the villagers), and the townspeople, the detectives (the one who does not believe in them is avenged, whereas the one who is open to get to know them, gets initiated himself).

Along with the conventions of the detective story, the conflict evolves from an initial situation lacking knowledge, towards the gradual unveiling of the mystery of the wild girls: the mythical is gradually revealed and juxtaposed to reality. In terms of the relationship between the word (the verbally expressed knowledge of the villagers) and the image (the visual into which the motion picture translates the verbal), the film seems not to have any special means to retain a dose of magic and in this way, along with the advancement of the investigation, the film loses its special taste of "magic realism," to the extent the wild girls become real, to the same extent the magic fades out. Witch Circle creates the magical in/through language, remaining the viewer's debtor in terms of aesthetic moments. It carries out the gesture of exoticising, assuming a colonial/voyeuristic gaze. 
The reflexive thematisation of feminity seems to be consciously assumed by Szabolcs Hajdú's directorial concept. However, this seems to be left unexplored by Dezső Zsigmond's unreflected camera. Since the medial images of women differ in the two films: whereas Witch Circle follows the pattern of the "woman within the image," that is, the woman subjected to the image, throwing the free and active woman into the captivity of an authoritative film narration instead of the captivity of peasant society, Mona Saparu, though being thrown into most humiliating conditions, drifting along passively according to the whims of fate, is active in an implied narratorial position: she interprets herself out of her conditions, thus she is in a way, through the activation of her imagination, the creator of her own image.

The ultimate reality of her being a sexual commodity turns into the realm of magic, and the viewer is free to interpret the escape-scene as a liberating gesture: removing the fetish-image from its usual place and "interpreting it out" of her conditions. However, this protective code system, working against the logic of passivity and exposure, seems not to go through the censorship of a male authority: the agent who urges Mona to tell her story, is not willing to accept the story infused with magic turns, and requires a translation of it into more simple terms. But Mona's magic seems to slip through the male authority: the fantasy gets saved beyond the records.

The IKEA-shop scene provides an open ending: on the one hand, it can be interpreted as the way reality restricts the possibility of creating and living in a dream world, on the other hand, it sustains the playful character of storytelling fantasy, even if only as a simulacrum (see the image of the sun on the computer screen). The resounding tones of Holy Night at the end of the film simultaneously introduce pathos, irony and social criticism into Mona's story, together with a post-romantic nostalgia of escapism, while the film leaves it unsolved whether the escape from reality is just a tale or reality itself.

As a conclusion regarding magic realism in the two discussed films, whereas Witch Circle merges magic into realism, Bibliothèque Pascal does the opposite, through its aesthetic moments it raises realism to the level of magic.

\section{Reality transgressing itself: Beyond the Hills}

In what follows, the cinematic representation of the woman victimised by the stereotypes created by social institutions will be discussed as it appears in Cristian Mungiu's Beyond the Hills (După dealuri, 2012). ${ }^{13}$

The film is two steps from the events that took place in 2005 and aroused a great media scandal. It is the adaptation of two non-fiction novels by Tatiana Niculescu Bran: Deadly Confession (Spovedanie la Tanacu, 2006), and Judges'

13 The film premiered at the 2012 Cannes Film Festival. 
Book (Cartea judecătorilor, 2007). Although deeply embedded in social realities, the film specifically creates fiction out of non-fiction by changing the names of the protagonists and by creating a fictitious place as the scene of action.

Both the book and the film offer a strong social reading of a series of events that did happen, though they bear a striking resemblance to fiction. And here we can detect a metalepsis: reality itself is fully suitable to be turned into novel and film, and the mediating act of the discussed artistic products turns the attention back to social realities. The question arises: what kind of reality do we live in, which is in itself ready-made fiction, which allows such cases to take place? What ideologies lie behind the real story rendered by the works of art, what does this story tell about institutions, religion, and about people themselves?

In the universe presented by the film it is the institution of religion, alongside with the health institution, that victimise the protagonist, marking a weird moral territory in which no one is to be blamed, everyone has their own truth. There is a cosy family atmosphere at the convent, a caressing spirit that surrounds Alina (Irina in Deadly Confession)—still, the unfolding of the events lead towards a practice of exorcism resulting in the girl's death, and it is very difficult to unambiguously point at the victimiser.

The world of the convent is a place ripped from time and space, a kind of non-place in Marc Augé's sense of the term. ${ }^{14}$ The title of the film also suggests that it is situated elsewhere, beyond the hills, but it can be added that it is also situated in another temporal dimension. Its relationship to the present, profane world is full of ruptures and contradictions, what is more, these ruptures and contradictions exist also within the confines of the convent.

Alina's pathological case creates a situation in the convent in the mirror of which these incompatibilities suddenly come to light. It is the girl's case that makes a connection between the institutions of religion and health, and something strange happens, as if the institutions exchanged their roles: no diagnosis is established in the hospital, as the doctors and nurses see the "soul" and not the body, while in the convent the priest and the nuns want to heal Alina by all means, even by resorting to the medieval practice of exorcism.

Another metalepsis that can be identified is how the institutional discourses repress and cover the visible signs of a bodily illness. When priest Daniel carries out the procedure of exorcism, he is satisfied to conclude that it has been successful, not even noticing that the patient is no longer alive. It is as if everybody lived in their own world, without these confined worlds ever reaching one another. There is no good or bad as there is no universally applicable code of interpretation-this element is strongly present in Zsolt Láng's short story entitled The Monastery of

14 "If a place can be defined as relational, historical and concerned with identity, then a space which cannot be defined as relational, or historical, or concerned with identity will be a nonplace.” (Augé 1995, 77-78) 
Protection ( $\mathrm{Az}$ oltalom kolostora) too, in the case of which the reader perceives the mediating presence of language and narration more powerfully than in Tatiana Niculesu Bran's Deadly Confession, which tries to mediate the story "as it was," objectively, without any moral comment, still, allowing a certain degree of irony in the almost naïve assimilation of everyone's dose of truth.

While no one can be individually blamed, there is an accumulation of individual irresponsibilities which lead to the death of the protagonist. The girl is the victim of the whole social apparatus. Her illness can be traced back to the fact that no social status emerges for her with the background that she has, the institutions of society hurry up to stigmatise a case like hers.

Two opportunities turn up in her life: going to the West and earning money, or going to the East, beyond the hills, into the convent, which, in its spirituality, does not refrain from taking her money away. In this way, an East-West opposition is created (similarly to Szabolcs Hajdú's Bibliothèque Pascal), a material as well as a spiritual alternative. However, neither is a real option, as nothing is what it seems to be or what it should be.

Her schizophrenia turns out to be the projection of the schizophrenia of society itself; in the absence of a real, supporting environment she loses the integrity of her personality, she loses her sanity. There is no place for her in society; she is a deviant element, especially with the sexually burdened past that she disposes of. Her self-esteem is marked by social stigmas, the film presents her story as the clash between her sexual libertinism and the primeval patriarchal order that she meets in the convent. She does not fit into the framework provided by institutions and mentalities; she is victimised by social taboos and stereotypes. It is this fictionreality amalgam that seems to demonstrate something about the heterotopic moral space which we live in, displaying incompatibilities and unsolvable paradoxes.

\section{Conclusion}

The examined films provide the possibility for us to examine issues related to imagology, such as the image of the East about the West (in Bibliothèque Pascal the Eastern European female body as an export commodity for the West; in Beyond the Hills the West as the alternative of the "oriental" monastery) or the social "reception" of otherness. They offer a complementary and intercultural image of the woman trapped between the East and the West, between social and religious institutions, and victimised by the stereotypical view of society. The brothel in Bibliothèque Pascal and the monastery in Beyond the Hills are two alternatives of non-places, in Marc Augé's sense of the term, the former representing a spatial version (the Eastern female body as a commodity transported to the West), the latter a temporal one (the female body victimised by medieval mentality). 
We have identified two distinct tendencies in Hungarian and Romanian cinema, drawing on distinct, apparently opposing tropes, namely excessive form/use of fiction and a low-key, minimalist one; still, they share an important feature, namely creating an imagery that, rendered through female alterity, defies the conventions and stereotypes created by classical (Hollywood) cinema and provide a disquieting field of critical reflection upon the always deferring, ultimately impalpable, unfathomable "reality." As one character in Zsolt Láng’s short story sums up: "In vein do they keep researching, they will never find out what happened in fact. As it is reality that is left out from every story" $(2008,282$, translated by me, J. P.).

\section{Works cited}

Augé, Marc. 1995. Non-Places. Introduction to an Anthropology of Supermodernity. Trans. John Howe. London-New York: Verso.

Bényei Tamás. 1997. Apokrif iratok. [Apocriphal Documents.] Debrecen: Kossuth Egyetemi Kiadó.

Butler, Judith. 1993. Bodies that Matter. On the Discursive Limits of "Sex." New York: Routledge.

Dánél Mónika. 2012. Surrogate Nature, Culture, Women-Inner Colonies. Postcolonial Readings of Contemporary Hungarian Films. Acta Universitatis Sapientiae, Film and Media Studies vol. 5: 107-128. http://www.acta.sapientia.ro/acta-film/C5/film5-7.pdf

De Beauvoir, Simone. 1949. The Second Sex. http://www.marxists.org/reference/ subject/ethics/de-beauvoir/2nd-sex/introduction.htm

Fulger, Mihai. 2006. „Noul val” în cinematografia românească. [The "New Wave” in Romanian Cinema.] Bucureşti: ART.

Havas Júlia Éva. 2011. Test-tanok. Kortárs magyar szerzői filmek nőképe. [BodyTenets. The Image of Woman in Contemporary Hungarian Auteur Films.] Metropolis vol. XV. no. 3: 30-41.

Király Hajnal. 2011. Könyv és film között. A hüségelven innen és túl. [Between Book and Film: Alternative Approaches to the Fidelity-Theory of Adaptations.] Cluj-Napoca: Koinónia.

Láng Zsolt. Az oltalom kolostora. In Hosszúfény. Határon túli magyar írók antológiája [Hosszúfény. Anthology of Hungarian Writers beyond the Border], ed. Vince Fekete, 258-284. Budapest: Magvető.

László Lilla. 2012. A nő terei egy kortárs magyar és román filmben. [Spaces of the Woman in Contemporary Hungarian and Romanian Cinema.] In $A$ tér értelmezései, az értelmezés terei [Interpretations of Space, Spaces of Interpretation], eds. Judit Pieldner and Zsuzsa Tapodi, 296-307. Cluj-NapocaMiercurea Ciuc: Societatea Muzeului Ardelean-Editura Status. 
Mulvey, Laura. 1975. Visual Pleasure and Narrative Cinema. Screen 16. no. 3.: 6-18. http://imlportfolio.usc.edu/ctcs505/mulveyVisualPleasureNarrativeCinema.pdf Niculescu Bran, Tatiana. 2012. Spovedanie la Tanacu. Roman. [Deadly Confession. A Novel.] Polirom. First edition: 2006, Humanitas.

—. 2013. Cartea Judecătorilor. [Judges’ Book.] Iaşi: Polirom. First edition: 2007, Humanitas.

Pop, Doru. 2010. The Grammar of the New Romanian Cinema. Acta Universitatis Sapientiae, Film and Media Studies vol. 3: 19-40. http://www.acta.sapientia. ro/acta-film/C3/film3-2.pdf

Részeg Imola. 2011. Múlt, történelem és emlékezés a kortárs román filmben. [Past, History and Memory in Contemporary Romanian Cinema.] In Kapcsolatok, képek. Imagológiai tanulmányok. [Connections, Images. Imagology Studies.], eds. Levente Pap and Zsuzsa Tapodi, 207-223. Miercurea Ciuc: Status.

Strausz László. 2011. Vissza a múltba. Az emlékezés tematikája fiatal magyar rendezőknél. [Back into the Past. The Topic of Memory with Young Hungarian Directors.] Metropolis vol. XV no. 3: 20-28.

\section{Figures}

Figs. 1-8. Witch Circle (Dezsô Zsigmond, 2009) vs. Bibliothèque Pascal (Szabolcs Hajdú, 2010)

The medial/narrative image of the woman:

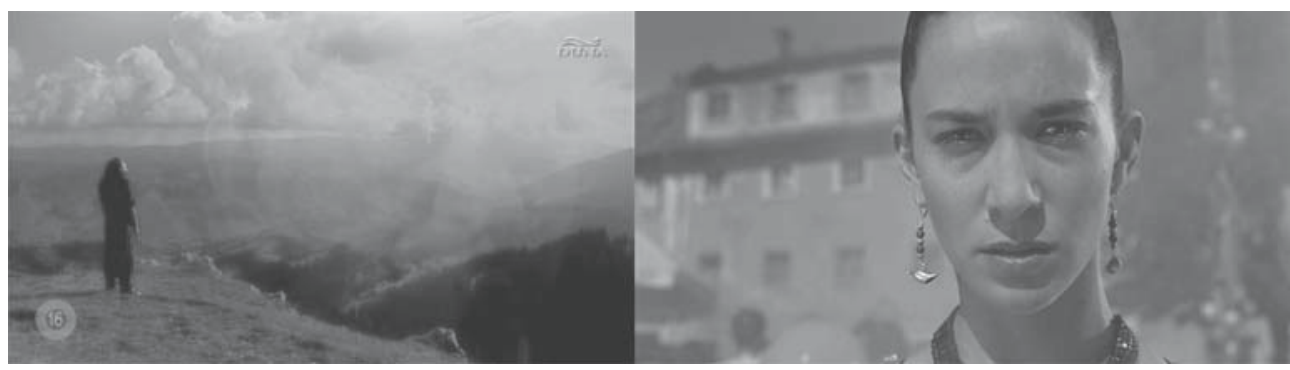

Outside social constraints vs. female identity as visual-sexual commodity:

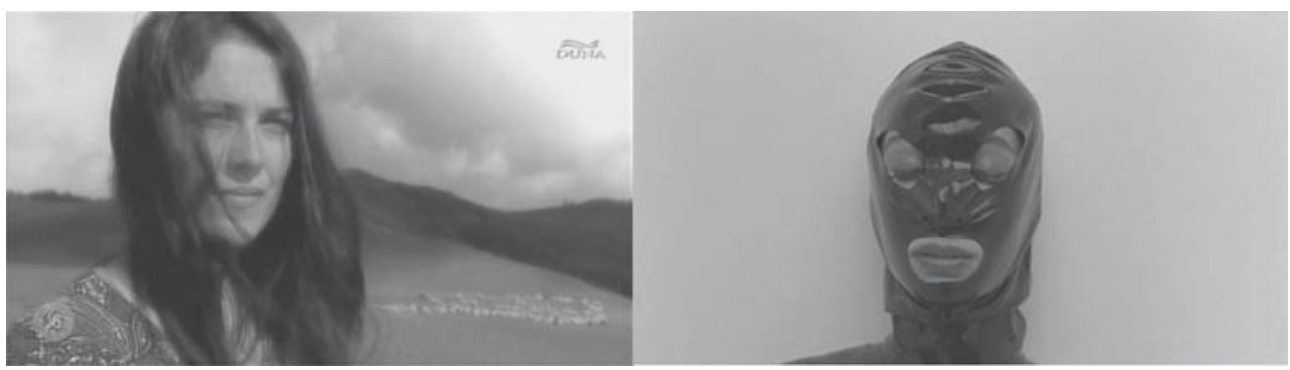


Realms of the imaginary:

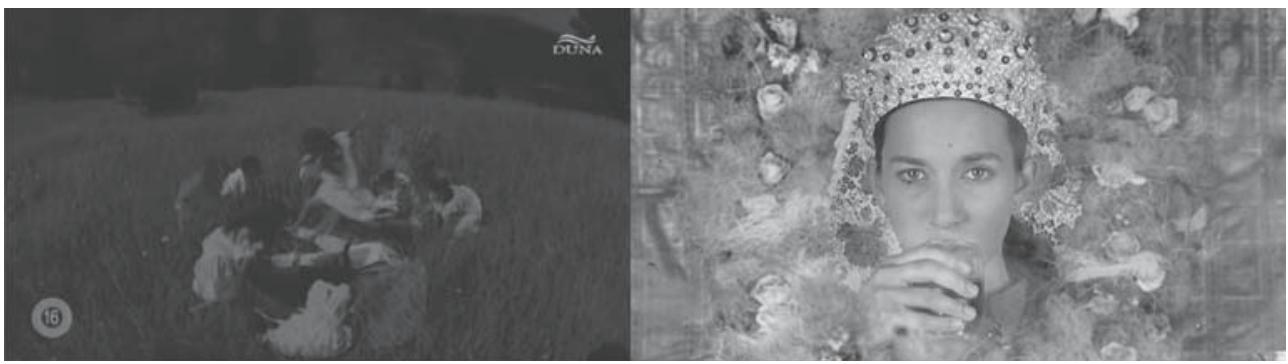

The glorification of the myth vs. the magic as simulacrum/reality supplement:

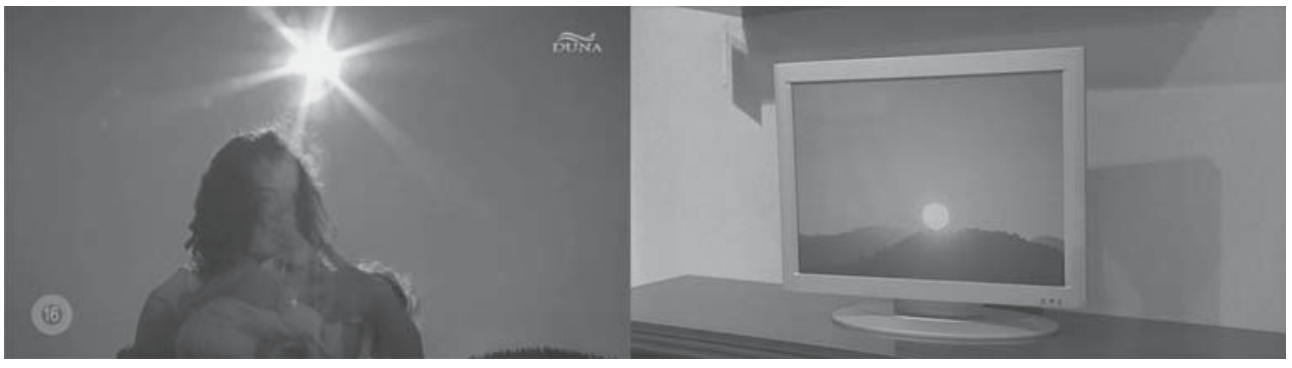

Figs. 9-15. Beyond the Hills (Cristian Mungiu, 2012)

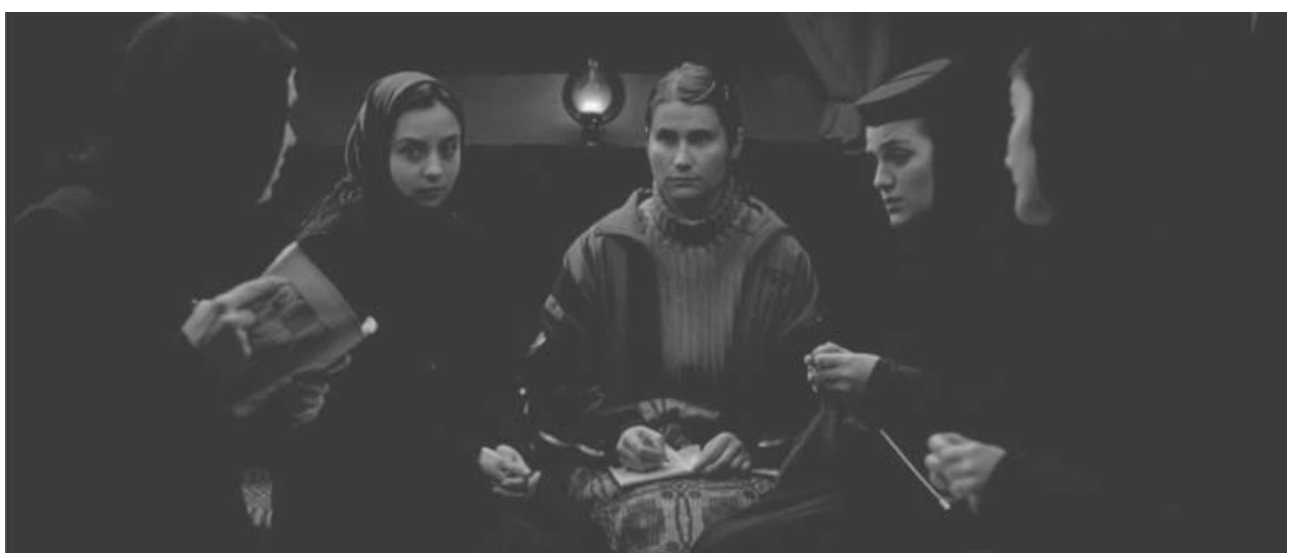



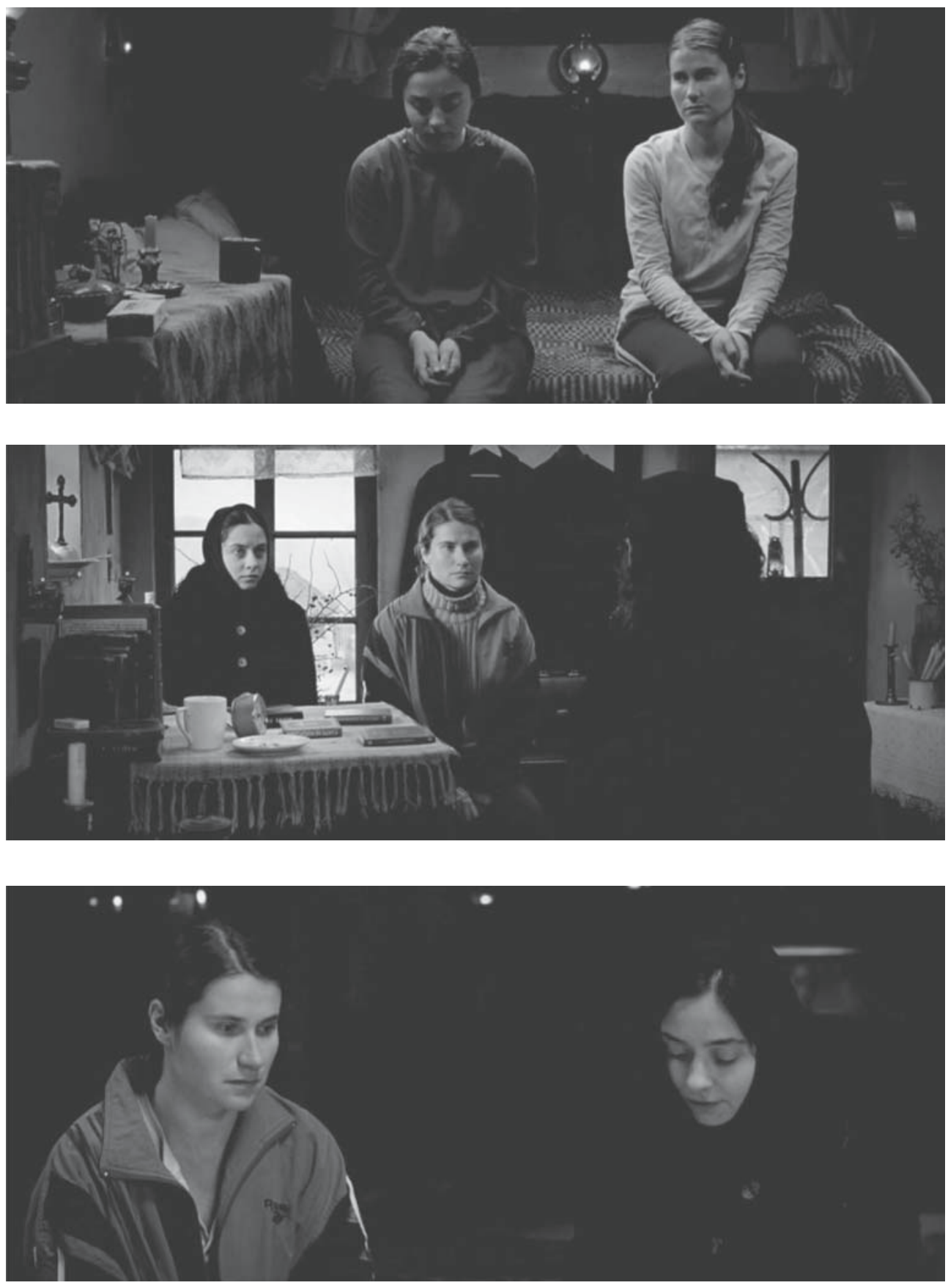

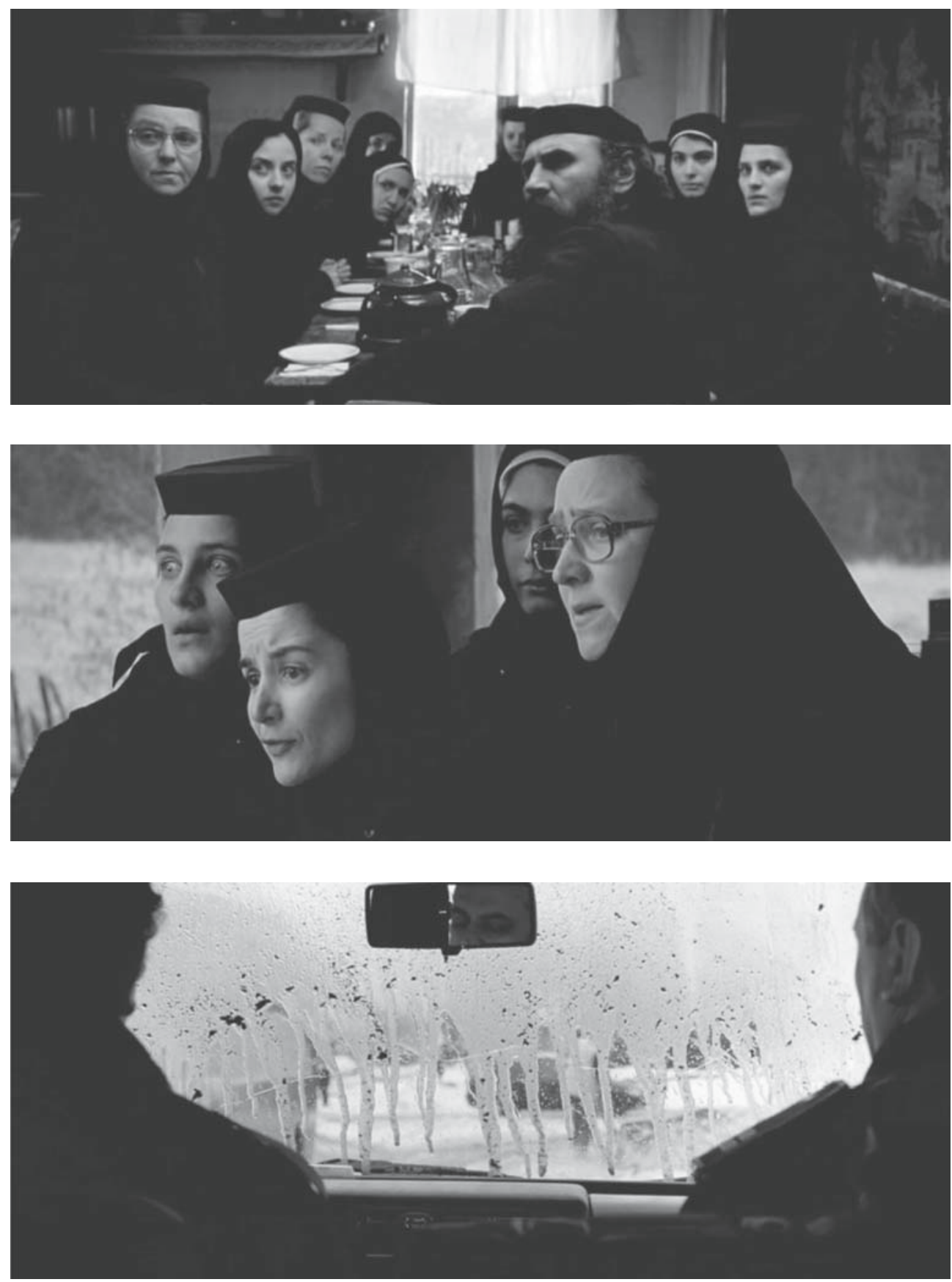